Przegląd Prawa Konstytucyjnego

-----ISSN 2082-1212-----

DOI 10.15804/ppk.2018.05.14

-----Nr 5 (45)/2018-----

Katarzyna Tomaszewska ${ }^{1}$

\title{
Realizacja ochrony interesu informacyjnego jednostki w ramach dostępu do informacji publicznej w świetle projektu ustawy o jawności życia publicznego
}

Słowa kluczowe: jawność, dostęp do informacji, nowe regulacje, informacja publiczna, wiedza publiczna

Keywords: openness, access to information, new regulations, public information, public knowledge

\section{Streszczenie}

Prawo do pozyskiwania wiedzy publicznej stało się w ostatnim czasie przedmiotem żywego zainteresowania. Przyczyn niniejszego stanu rzeczy należy doszukiwać się w działaniach nad ustanowieniem nowych regulacji (ustawy o jawności życia publicznego), które mają zastąpić m.in. obowiązującą od 2001 r. ustawę z 6 września o dostępie do informacji publicznej. Oceniany negatywnie projekt ustawy o jawności życia publicznego wprowadza szereg modyfikacji dotychczasowych uregulowań, które gwarantują pozyskiwanie informacji o sprawach publicznych. Wprowadza nowe instytucje oraz tworzy podstawy dla występowania nowych „mechanizmów dostępowych” (mniej lub bardziej nakierowanych na poszerzanie realizacji ochrony interesu informacyjnego jednostki). Wyodrębnieniu niniejszych i przeprowadzeniu ich oceny poświęcone jest niniejsze opracowanie.

1 ORCIDID: 0000-0003-4024-0036, doktor, Centrum Badań Problemów PrawnychiEkonomicznych Komunikacji Elektronicznej Wydział Prawa, Administracji i Ekonomii Uniwersytet Wrocławski. E-mail: katarzyna.tomaszewska@uwr.edu.pl. 


\section{Summary}

\section{Implementation of the protection of the information interest of the entity as part of access to public information in the light of the draft law on transparency of public life}

The right to gain public knowledge has recently become a matter of keen concern. Reasons of that state of affairs should be read into actions in establishment new regulations (The Openness of Public Life act) which are going to replace current act from 6 September 2018 Access to Public Information act. Negatively assessed project about "Openness of Public Life act" implements array of adjustments of current regulations which guarantee obtaining information about public affairs. It also implements new institutions and creates grounds for the occurrence of new "access methods" (more or less directed on broadening the implementation of the information protection interest of the unit). The study is devoted to isolate mentioned above and their judgment.

\section{Wprowadzenie}

Odnajdująca podstawy w powszechnym prawie do informacji (art. 61 Konstytucji $\mathrm{RP}^{2}$ ) konstrukcja dostępu do wiedzy publicznej stała się w ostatnim czasie przedmiotem żywego zainteresowania. Przyczyn niniejszego stanu rzeczy należy poszukiwać w prowadzonych działaniach nad ustanowieniem nowych regulacji, które mają zastąpić m.in. obowiązującą od 2001 r. ustawę z 6 września o dostępie do informacji publicznej ${ }^{3}$ (dalej zw. u.d.i.p.). Chodzi w tym wypadku o powszechnie komentowany projekt ustawy o jawności życia publicznego (dalej zw. p.u.j.ż.p. $)^{4}$. Co istotne szereg ocen odnoszących się do projektowanych zmian, czy też dotyczących nowo ustanawianych in-

2 Konstytucja z 2 kwietnia 1997 r. (Dz.U. Nr 78, poz. 483 ze zm.).

3 Ustawa z 6 września 2001 r. o dostępie do informacji publicznej (Dz.U. 2016, poz. 1764 ze zm.).

4 http://www.jawnosc.pl/?p=3438 (21.04.2018). Zmiana objęła następujące ustawodawstwo: ustawę z 21 sierpnia 1997 r. o ograniczeniu prowadzenia działalności gospodarczej przez osoby pełniące funkcje publiczne (Dz.U. 2017, poz. 1393), ustawę z 7 lipca 2005 r. o działalności lobbingowej w procesie stanowienia prawa (Dz.U. 2017, poz. 248), ustawę z 6 września 2001 r. o dostęp do informacji publicznej (Dz.U. 2016, poz. 1764 ze zm.). 
stytucji wypada niekorzystnie ${ }^{5}$. Analiza tego rodzaju opinii może prowadzić do „osłabienia” założenia o posiadaniu przez kategorię dostępu do wiedzy publicznej statusu instytucji ochrony interesu jednostki. Z tego też względu zasadniczym celem niniejszego opracowania jest przyjrzenie się projektowanym zmianom i jednoznaczne ustalenie czy wraz z wejściem w życie u.o.j.ż.p. będzie można mówić o zmodyfikowaniu założenia względem realizacji ochrony interesu informacyjnego jednostki? Czy może w obrębie tzw. nowego ustawodawstwa będzie możliwym odnalezienie zmian korzystnych z punktu widzenia realizacji postulatu transparentności życia publicznego i ochrony interesu informacyjnego jednostki? Ustalenie niniejszego wydaje się być o tyle ważne, albowiem już w samym uzasadnieniu do projektu zostało podniesione, że głównym celem planowanego ustawodawstwa jest wzmocnienie transparentności funkcjonowania państwa i działających $\mathrm{w}$ jego imieniu organów ${ }^{6}$. Dzięki niniejszym przepisom ma zostać wzmocniona przejrzystość zarządzania państwem i jego środkami. Ma dojść do wzmocnienia kontroli zarówno instytucjonalnej jak i społecznej, sama zaś u.j.ż.p. ma stanowić podbudowę dla ukształtowania silnych mechanizmów antykorupcyjnych w kraju ${ }^{8}$.

W samym założeniu istota p.u.j.ż.p. sprowadza się do uporządkowania obecnie istniejących regulacji, ale również do utworzenia nowych (nieznanych dotąd w polskim systemie prawnym) rozwiązań w zakresie szerokiego udostępniania informacji publicznych ${ }^{9}$. Jest to czynione z myślą o zagwarantowaniu możliwie najszerszej ochrony interesu informacyjnego społeczeństwa oraz jego poszczególnych jednostek. Chodzi w tym wypadku o prawnie chroniony interes jednostki związany z gwarantowanymi przez państwo

\footnotetext{
5 Chodzi w tym wypadku o oceny prezentowane przez przedstawicieli doktryny, dziennikarzy i publicystów. http://www.lex.pl/czytaj/-/artykul/ustawa-o-jawnosci-zycia-publicznego-moze-bycsprzeczna-z-rodo, http://www.rp.pl/Urzednicy/301239961-Opinia-RPO-w-sprawie-projektu-ustawyo-jawnosci-zycia-publicznego.html, https://www.pwc.pl/pl/artykuly/2018/ustawa-o-jawnosci-zyciapublicznego.html, http://www.riskcompliance.pl/news/o-jawnosci-sygnalistach-i-korupcji-na-gruncieprojektu-ustawy-o-jawnosci-zycia-publicznego-2/, https://samorzad.infor.pl/sektor/organizacja/ prawo_administracyjne/770042,Oswiadczenia-majatkowe-w-JST-w-swietle-projektu-ustawy-ojawnosci-zycia-publicznego.html (29.07.2018).

6 Uzasadnienie do p.u.j.ż.p., http://www.jawnosc.pl/?p=3438 (7.05.2018).

7 Ibidem.

8 Uzasadnienie do p.u.j.ż.p., http://www.jawnosc.pl/?p=3438 (7.05.2018).

9 Ibidem.
} 
możliwościami samodzielnego pozyskiwania informacji i otrzymywania ich na żądanie, celem zaspokojenia potrzeb własnych i potrzeb ogółu społeczeństwa. Nie jest wykluczone, aby udzielanie informacji (będące formą realizacji interesu publicznego) pozostawało w zbieżności z zaspokajaniem indywidualnych interesów jednostek ${ }^{10}$. Odwołując się do samej zawartości p.u.j.ż.p. należy wskazać na rozmaitość planowanych modyfikacji w obszarze udostępniania wiedzy publicznej. Sprowadzają się one:

- po pierwsze - do wprowadzania nowych instytucji prawnych;

- $\quad$ po drugie - do ukształtowania nowych pojęć, bądź też do wyjaśnienia tych, które uprzednio występowały, ale stanowiły jedynie pojęcia niedookreślone;

- po trzecie - do odmiennego nadania treści i znaczenia regulacjom dotychczas występującym na gruncie u.d.i.p.,

- $\quad$ po czwarte - do utworzenia lub też do poszerzenia występujących na gruncie u.d.i.p. katalogów podmiotowych oraz przedmiotowych ${ }^{11}$.

\section{Pojęcie informacji publicznej}

Rozpoczynając rozważania w pierwszej kolejności należy odnieść się do kwestii kreowania nowych definicji na płaszczyźnie uregulowań p.u.j.ż.p. Chodzi w tym wypadku o ukształtowanie nowej - ustawowej definicji informacji publicznej oraz informacji przetworzonej uprzednio nieistniejącej na gruncie u.d.i.p., ale wyprowadzanej na potrzeby realizacji wniosków informacyjnych przez doktrynę oraz orzecznictwo. Ogólnie określając tego rodzaju zabieg zasługuje na pozytywną ocenę, albowiem posługiwanie się przez ustawodawcę pojęciami niejasnymi, wieloznacznymi czy też niedookreślonymi nastręcza trudności w procesie prawidłowego realizowania oczekiwań informacyjnych.

Za koniecznością prawidłowego zdefiniowania pojęcia informacji publicznej przemawia m.in. fakt odwoływania się do niego przez ustawodawcę

10 J. Taczkowska-Olszewska, Dostęp do informacji publicznej w polskim systemie prawnym, Warszawa 2014, s. 130.

11 Co istotne przedstawiony powyżej podział nie ma charakteru dychotomicznego - rozłącznego. Niemożliwym jest wydzielenie zupełnie odrębnych i jednocześnie jednoznacznych grup, a poszczególne części składowe przecinają się wzajemnie towarzysząc innym występującym obok elementom. Uwidacznia się to przy okazji omawiania poszczególnych fragmentów projektowanej zmiany. 
w uregulowaniach szczególnych, które w sposób odmienny determinują formy, sposoby czy też procedurę udostępnienia wiedzy publicznej, zachowując przy tym jej ustrojową - ogólnie określaną (zdeterminowaną treścią u.d.i.p.) interpretację ${ }^{12}$. Przywołując występujące od samego początku obowiązywania u.d.i.p. pojęcie informacji publicznej jako informacji o sprawach publicznych, nie sposób nie nadmienić o towarzyszących jego występowaniu problemach natury interpretacyjnej. Błąd logiczny określany jako ignotum per ignotum (niejasne definiowane przez niedookreślone) pozostawia podmiotom zobowiązanym informacyjnie szeroki zakres swobody w zakresie kwalifikowania informacji jako publicznych, bądź też jako niepublicznych i tym samym niezasługujących na udostępnienie. W rozwiązywaniu niniejszych problemów nie pomaga również otwarty katalog spraw (art. 6 u.d.i.p.), o których to informacje stanowią wiedzę publiczną. Tego rodzaju uregulowanie posiada raczej znaczenie porządkujące aniżeli regulacyjne czy też definicyjne ${ }^{13}$. Stwarza możliwość zakwalifikowania określonych informacji wprost za publiczne a zatem podlegające udostępnieniu oraz wymienia poszczególne choć niejednoznaczne grupy danych odnoszących się do tzw. sfery publicznej ${ }^{14}$.

$\mathrm{Z}$ drugiej jednakże strony literatura przedmiotu uwidacznia również występowanie stanowisk, w świetle to których w zawartości art. 1 ust. 1 u.d.i.p. doszukiwano się pozytywnego nastawienia ustawodawcy względem procesu rozpowszechniania wiedzy publicznej. W tym sformułowaniu „informacji o sprawach publicznych" omawiany fragment konstrukcji jawności przybiera charakter generalny i powszechny. Obejmuje zakresem danych publicznych szeroką gamę informacji i faktów o zdarzeniach, o strukturach, o publicznych środkach finansowych ${ }^{15}$. Ostateczne jednakże rozstrzygnięcie sporów powstałych na niniejszym tle pozostawiono sądom administracyjnym, które w procesie identyfikowania danych za publiczne lub też za niepubliczne

12 Stosownie do zwartości art. 1 ust. 2 u.d.i.p jej przepisy nie naruszają przepisów innych ustaw określających odmienne zasady i tryb dostępu do informacji będących informacjami publicznymi... Podobne uregulowania można odnaleźć na płaszczyźnie p.u.j.ż.p. (art. 3 ust. 1).

13 S. Szuster, Komentarz do art. 6 ustawy o dostępie do informacji publicznej, [w:] Komentarz do ustawy z dnia 6 września 2001 r o dostępie do informacji publicznej, red. M. Kłączyński, S. Szuster, System Informacji Prawnej Lex, - podaję za D. Fleszer, Dostęp do danych publicznych na przykładzie aktu administracyjnego, [w:] Jawność w samorządzie terytorialnym, red. B. Dolnicki, Warszawa 2015, s. 212.

14 Ibidem.

15 A. Bobiec, Informacja publiczna a ochrona prywatności osób petniących funkcje publiczne, [w: ] Jawność w samorządzie..., s. 56. 
(prywatne) wykorzystują dotychczasowe sposoby definiowania przedmiotowego pojęcia pochodzące od doktryny oraz judykatury. Rozmaicie oceniany zabieg ustawodawcy występujący w omawianym zakresie nie posiada przypadkowego charakteru. Celowość jego zastosowania sprowadza się do objęcia zakresem kontroli społecznej (realizowanej przy pomocy dostępu do informacji publicznej) możliwe jak najszerszy obszar działalności państwa, jego organów i innych podmiotów dysponujących środkami publicznymi ${ }^{16}$.

Nie jest tajemnicą, że w procesie definiowania informacji publicznej dominujące znaczenie posiada zakres merytoryczny zawartości art. 61 Konstytucji RP. Warto w tym miejscu przypomnieć, że to właśnie do czasu uchwalenia aktualnie obowiązującej ustawy zasadniczej prawo do informacji występowało w polskim systemie prawnym jedynie w ograniczonym zakresie $^{17}$. Sprowadzało się ono jedynie do legitymacji przysługującej stronom i innym uczestnikom postępowania, a jej treścią było przyznanie jednostkom uprawnienia do tego, aby być w pełni poinformowanym o prowadzonych przez organy (a ich dotyczących) postępowaniach ${ }^{18}$. Konstytucyjne ustanowienie i uregulowanie kwestii dostępu do wiedzy publicznej zasługuje na pozytywną ocenę. Stanowi przejaw dbałości ustrojodawcy o państwo i o jego obywateli ${ }^{19}$. Za informację publiczną należy uznać informację obrazującą aktualny stan wiedzy o sferze publicznej, która znajduje się w posiadaniu (jest wytworzona lub odnoszona do podmiotów wykonujących funkcje publiczne w zakresie realizacji zadań władzy publicznej i gospodarowania mieniem komunalnym lub majątkiem Skarbu Państwa) ${ }^{20}$. Powinna być ona udostępniona w sposób przejrzysty, tak aby była w pełni zrozumiała dla przeciętnego obywatela ${ }^{21}$. „Informacją publiczną są nie tylko dokumenty bezpośrednio redagowane i wytworzone przez organy administracji

16 T. Bojar-Fijałkowski, Dostęp do informacji publicznej - wybrane zagadnienia materialno-prawne i proceduralne z uwzględnieniem informacji o środowisku i jego ochronie jako szczególnego rodzaju informacji publicznej, [w:] Dostęp do informacji publicznej. Wybrane aspekty teorii i praktyki, red. A. Lusińska, A. Kalinowska- Żeleźnik, Gdańsk 2014, s. 13.

17 Jawność w samorzadzie..., s. 19.

18 Ibidem.

19 L. Bielecki,J. Stelmasiak, Zasada jawności działania organów powiatu, [w:] Jawność w samorzadzie..., s. 45 .

20 Wyrok NSA z 7 marca 2012 r., I OSK 2265/11, http://orzeczenia.nsa.gov.pl/doc/BFC87465F2 (6.01.2018) oraz wyrok WSA w Warszawie z 4 lipca 2012 r., II SAB/Wa 66/12, http://www.lexlege.pl/ orzeczenie/259208/ii-sab-wa-66-12-wyrok-wojewodzki-sad-administracyjny-w-warszawie/(6.01.2018).

21 Ibidem. 
publicznej, ale również tego rodzaju dokumentacja, której używają one do zrealizowania powierzonych im prawem zadań" 22 . Takie też stanowisko - stanowisko względem podmiotowego i jednocześnie szerokiego kwalifikowania wiedzy publicznej pojawia się na gruncie p.u.j.ż.p. Planowana zmiana ustawodawstwa w przedmiocie dostępu do wiedzy publicznej w rzeczywistości nie tylko nie kreuje nowego pojęcia, ale i również w żadnym razie nie można uznać, że nadaje mu jakiegoś szczególnego, czy też nowatorskiego znaczenia. Art. 2 pkt. 2 p.u.j.ż.p. stanowi ustawowe powtórzenie regulacji konstytucyjnej przyznającej obywatelom szerokie uprawnienie do zdobywania informacji określanej jako publiczna. W jej ramach punkt ciężkości jest położony na tzw. działalność publiczną (związaną z realizacją zadań publicznych i z dysponowaniem funduszami publicznymi przez rozmaite podmioty). Tego rodzaju definiowanie jest jak najbardziej rozległe i nie do końca sprecyzowane. Słusznie jednak jest ono interpretowane szeroko zarówno z punktu widzenia podmiotowego jak i przedmiotowego. Z drugiej jednakże strony nie należy zapominać, że wprawdzie przedstawiony powyżej proces definiowania nie wprowadza nowego postrzegania informacji publicznej, ale eliminuje istnienie defektu logicznego, na który wskazywał T. Aleksandrowicz ${ }^{23}$ i na występowanie którego powoływała się doktryna deprecjonując przy tym prawidłowość uregulowań u.d.i.p. Nie jest tajemnicą, że jednoznaczne określenie tego, co jest informacją publiczną nie jest możliwe, podobnie jak stworzenie zamkniętego katalogu spraw, o których dane stanowią wiedzę publiczną. Ponadto definiowanie występujące na gruncie p.u.j.ż.p. ogranicza konieczność swobodnej interpretacji pojęć (pierwotnie niedookreślonych) przez same podmioty zobowiązane informacyjnie.

\section{Pojęcie informacji przetworzonej}

W drugiej kolejności warto zwrócić uwagę na definiowanie jednej z kategorii informacji publicznej posiadającej status informacji złożonej. Chodzi w tym wypadku o informację przetworzoną przywoływaną na gruncie uregulowań u.d.i.p., choć nieposiadającą własnej ustawowej interpretacji.

22 Wyrok NSA z 3 stycznia 2013 r., I OSK 2311/12, http://orzeczenia.nsa.gov.pl/doc/FCA80D3E72 (6.01.2018).

23 T. Aleksandrowicz, Komentarz do ustawy o dostępie do informacji publicznej, Warszawa 2008, s. 94. 
Odmiennie sytuacja wygląda jeśli chodzi o regulacje p.u.j.ż.p. Projektodawca determinuje znaczenie tego rodzaju informacji publicznej wskazując w pkt. 4 art. 1, iż jest nią informacja, której podmiot zobowiązany informacyjnie nie posiada $\mathrm{w}$ momencie wpływu wniosku o udostępnienie informacji publicznej, ale wytwarza ją dla ubiegającego się w oparciu o posiadane zasoby informacyjne. Do jej wytworzenia wymagane są jednak dodatkowe nakłady o charakterze osobowym, rzeczowym czy też finansowym. Zawężenia tak szeroko i jednocześnie niejednoznacznie określonego zabiegu przetworzenia należy upatrywać w dokonanych przez projektodawcę wykluczeniach ustawowych, które sprowadzają się do wyeliminowania z pojęcia przetworzenia procesu skanowania, anonimizacji, bądź też prostego zestawienia danych wyczerpujących znamiona wiedzy publicznej. Co ważne potencjalne zagrożenie w postaci twierdzenia o ograniczeniu procesu udostępniania wiedzy publicznej na skutek niejednoznacznego definiowania procesu przetworzenia nie posiada w rzeczywistości racji bytu. Potrzeba zdefiniowania procesu przetworzenia pojawiła się w doktrynie i praktyce już znacznie wcześniej (o czym świadczy liczne orzecznictwo dążące do zobrazowania tego, które czynności osoby działającej w imieniu podmiotu zobowiązanego informacyjnie można uznać za proces przetworzenia a które nie). Judykatura jednoznacznie wskazuje, że proces anonimizacji będący swoistego rodzaju instrumentem ograniczania procesu realizacji dostępu do wiedzy publicznej z racji swojego ściśle technicznego charakteru, nie może być kwalifikowany jako proces przetworzenia prostych informacji publicznych ${ }^{24}$.

\section{Szczególna istotność dla interesu publicznego}

W zakresie procesu przetworzenia obok pojawiającej się po raz pierwszy na gruncie p.u.j.ż.p. definicji ustawowej uwidacznia się również kierunek modyfikacji tzw. trzeciego rodzaju. Chodzi w tym wypadku o aspekt legity-

24 Wyrok NSA z 9 sierpnia 2011 r., I OSK 977/11, http://orzeczenia.nsa.gov.pl/doc/43B4BE205D (23.04.2018), zob. stanowisko P. Sitniewskiego, P. Sitniewski, Nowe zasady dostępu do informacji publicznejustawa o jawności życia publicznego, „Informacja w administracji publicznej” 2018, nr 1, System Informacji Prawnej Legalis, http://sip.legalis.pl/document-full.seam?documentId=mjxw62zogi3damjzga3dkmq (3.05.2018). 
mowania się przez zainteresowanego określonego rodzaju interesem, który przesądza o zasadności podejmowania dodatkowych działań ze strony podmiotu zobowiązanego informacyjnie. W tym zakresie projektodawca zmierza do zmodyfikowania istniejących uregulowań u.d.i.p. odnoszących się do szczególnego „uargumentowania” celowości procesu przetworzenia. Uzyskanie informacji przetworzonej (w myśl p.u.j.ż.p) pociąga za sobą konieczność uzasadnienia jedynie istotnego interesu publicznego, a nie szczególnie istotnego interesu publicznego (tak jak to ma miejsce pod rządami aktualnie obowiązującej u.d.i.p.) W tym wypadku opierając się wyłącznie na tzw. językowym podejściu względem projektowanego „zabiegu” ustawodawcy, należałoby stanąć na stanowisku o pro - ochronnym nastawieniu względem procesu udostępniania. Tego rodzaju sformułowanie (wbrew samym pozytywnie ocenianym zamierzeniom) może tworzyć jedynie iluzoryczny obraz dążenia do poszerzenia zakresu zobowiązań informacyjnych, czy też z drugiej strony do ograniczenia możliwości uchylania się od realizacji zobowiązania informacyjnego z powołaniem się na niemożność wykazania tzw. szczególnej istotności dla interesu publicznego. Posłużenie się w tym wypadku określeniem dotyczącym jedynie iluzorycznego charakteru działania na korzyść interesu informacyjnego jednostki nie jest przypadkowe. Owszem wprawdzie dostrzegalnym jest zmniejszenie natężenia owej istotności, ale to w rzeczywistości może niewiele zmienić i może nie przynieść żadnych wymiernych korzyści dla podmiotu faktycznie zainteresowanego. Tego rodzaju założenie tym bardziej wydaje się zasadne w obliczu realnych trudności z interpretacją kwestii istotności dla interesu publicznego. Nadal projektodawca (podobnie jak ustawodawca) pozostawia kwestię oszacowania czy podmiot zobowiązany powinien podjąć dodatkowy wysiłek jemu samemu. Oceniane negatywnie uregulowanie (art. 3 ust. 1 pkt. 1 u.d.i.p.) pozostawiające zbyt duży zakres swobody podmiotowi zobowiązanemu informacyjnie nie ulega większej zmianie wraz z pojawieniem się p.u.j.ż.p. Odnosząc się do konieczności wykazania (aktualnie wymaganej) szczególnej istotności należy wskazać na:

- Konieczność wykazania potrzeby zdobycia wiedzy ważnej nie tylko dla zainteresowanego działającego subiektywnie, ale również dla innych podmiotów, które jednakowoż w danym momencie nie wykazują zainteresowania informacyjnego (ale obiektywnie określając mogliby być również zainteresowanymi - tzw. zainteresowanie obiektywne); 
- Konieczność wykazania tzw. działania nie tylko dla siebie, ale również dla innych (z myślą o innych);

- Konieczność wykazania, że jego działanie służy społecznie akceptowalnym potrzebom, które pozostają w związku z dążeniem do poprawy funkcjonowania struktur administracyjnych, czy też społecznych ${ }^{25}$.

P. Szustakiewicz uwidacznia trzy elementy kwalifikacyjne przemawiające za udostępnieniem informacji przetworzonej w świetle u.d.i.p.: działanie w interesie publicznym, istotność dla interesu publicznego, stopień szczególnej istotności ${ }^{26}$. Podkreśla jednocześnie, że wraz z wejściem w życie nowych (p.u.j.ż.p.) ich liczba ulegnie zmniejszeniu ${ }^{27}$ (na skutek obniżenia stopnia natężenia ze szczególnej istotności do „umiarkowanej” istotności). Niemniej jednak to dopiero orzecznictwo sądów administracyjnych uwidoczni tzw. realność zmiany i ewentualne jej pozytywne następstwa ${ }^{28}$.

Od strony proceduralnej należy zauważyć, że projektodawca po raz pierwszy ustanawia termin w ciągu którego podmiot zobowiązany informacyjnie występuje do wnioskodawcy o uzasadnienie wniosku. Wynosi on 7 dni od dnia przedłożenia wniosku i w żadnym razie nie wpływa niekorzystnie na ostateczny termin rozpatrzenia sprawy. Termin na załatwienie „sprawy” biegnie od momentu uzasadnienia wniosku przez zainteresowanego. W tym zakresie pomimo braku wyraźnego określenia, projektodawca stanął na stanowisku że na etapie „pierwotnego” wnioskowania o udostępnienie wiedzy publicznej, wnioskodawca nie musi wiedzieć (i najczęściej nie wie), iż oczekiwana przez niego informacja wyczerpuje znamiona informacji złożonej - przetworzonej. To implikuje jednoczesne twierdzenie, że na tym etapie (podobnie jak pod rządami obowiązujących regulacji) nie musi od razu wykazywać istotności dla interesu publicznego. Obligatoryjność niniejszego powstaje wraz z momentem wezwania przez podmiot zobowiązany informacyjnie do uzupełnienia wniosku w terminie $7 \mathrm{dni}$. Terminy uprawniające do przedłożenia odwołania biegną wówczas od dnia uzasadnienia wniosku przez zainteresowanego.

25 K. Kędzierska, P. Szustakiewicz, Pojęcie informacji publicznej, [w:] Dostęp do informacji publicznej, red. P. Szustakiewicz, Warszawa 2016, s. 43.

26 P. Sitniewski, op.cit.

27 Ibidem.

28 Ibidem. 


\section{Uzasadnienie wniosku informacyjnego}

Analizując kwestię konieczności wykazywania przez zainteresowanego informacyjnie istotności dla interesu publicznego (ogólnie określając potrzeby uzasadnienia zainteresowania informacją publiczną) nie sposób nie zwrócić uwagi na zmiany występujące w obrębie podstawowych warunków ubiegania się o udostępnienie informacji publicznej. Chodzi w tym wypadku o sytuację ubiegania się przez zainteresowanego o tzw. informację prostą, której pozyskanie prowadzi do zaspokojenia interesu faktycznego a uwzględniając zawartość uregulowań u.d.i.p. i uregulowań szczególnych, determinuje również ochronę interesu prawnego jednostki. Jak zostało już uprzednio wskazane proces udostępniania ma na celu dostarczanie wiedzy koniecznej dla potrzeb społecznego kontrolowania. Dostęp do informacji publicznych jest instytucją kontrolowania obywatelskiego, ale i jednocześnie służy ochronie interesów informacyjnych poszczególnych jednostek. Uwidacznia się to w szczególności na gruncie uregulowań z zakresu materialnego prawa administracyjnego oraz gospodarczego. To jednak nie jest równoznaczne z koniecznością legitymowania się tego rodzaju interesem przez zainteresowanego, nie pociąga za sobą konieczności dowodzenia niniejszego przed podmiotem zobowiązanym informacyjnie. Warto zauważyć, że podobnie jak na gruncie art. 2 ust. 2 u.d.i.p. projektodawca zajmuje stanowisko w świetle którego nie ma obligatoryjności uzasadniania potrzeb informacyjnych jednostki. Co jednak ważne dokonując porównania obowiązujących i projektowanych uregulowań prawnych (u.d.i.p. oraz p.o.j.ż.p.) zastanawiającym jest dlaczego na gruncie planowanych zmian podjęto kroki prowadzące do niemożności postawienia pomiędzy nimi znaku równości. Stosownie do treści art. 2 ust. 2 u.d.i.p. od osoby wykonującej prawo do informacji publicznej nie wolno żądać wykazania interesu prawnego lub faktycznego. Z kolei art. 4 ust. 2 p.o.j.ż.p. wskazuje jedynie na fakt nieżądania przez podmiot zobowiązany informacyjnie wykazywania interesu prawnego lub faktycznego. Bez wątpienia aktualne brzmienie uregulowania art. 2 ust. 2 przybiera postać nakazu, podczas gdy art. 4 ust. 2 determinuje pewnego rodzaju twierdzenie o istniejącym stanie rzeczy. $\mathrm{Na}$ tej płaszczyźnie można by pokusić się o twierdzenie, że dotychczasowa praktyka i stosunkowo długotrwałe obowiązywanie uregulowań u.d.i.p doprowadziło do wypracowania pewnego rodzaju polityki procesu udostępniania - polity- 
ki, w ramach której współczesne podmioty zobowiązane informacyjnie mają świadomość swoich powinności oraz prawidłowości przebiegu procesu udostępniania i są już dalekie od przesadnego uchylania się od obowiązków informacyjnych (wszelkimi dostępnymi sposobami) ${ }^{29}$. Jednoznaczne ustalenie zasadności czy też niezasadności niniejszego twierdzenia wymagałoby gruntownego przeanalizowania występującej na przestrzeni lat praktyki w zakresie udostępniania wiedzy publicznej.

\section{Wymagany termin na załatwienie roszczenia informacyjnego}

Od strony procesowej istotne znaczenie (w szczególności z punktu widzenia prowadzonych rozważań) posiada określenie terminu na realizację zobowiązania informacyjnego. W grę wchodzi w tym wypadku ustawowe skrócenie tzw. ostatecznego terminu na udostępnienie informacji publicznej z uprzednio gwarantowanego terminu $60 \mathrm{dni}$, ograniczając tym samym potencjalny czas oczekiwania jednostek zainteresowanych informacyjnie. W myśl art. 15 p.u.j.ż.p. udostępnienie informacji publicznej następuje bez zbędnej zwłoki, nie później jednakże niż w ciągu 14 od dnia złożenia wniosku. Jeżeli informacja nie może być udostępniona w powyższym terminie podmiot zobowiązany informacyjnie powiadamia o powodach opóźnienia, o terminie w którym dojdzie do spełnienia obowiązku informacyjnego (takiego, który nie przekroczy 30 dni od dnia pierwotnego skierowania zainteresowania przez jednostkę).

\section{Udostępnianie informacji przy pomocy elektronicznego biuletynu}

W prowadzonych rozważaniach koniecznym wydaje się również zwrócenie uwagi na sferę (zasadniczo korzystnie ocenianych z punktu widzenia zainteresowanej jednostki) zmian przebiegających w obrębie tzw. bezwnioskowej formy upubliczniania danych noszących znamiona wiedzy publicznej. Generalnie określając chodzi o wyraźne podkreślenie zasady pierwszeństwa trybu bezwnioskowego - w szczególności zaś realizowanej przy pomocy elektronicz-

29 Ciekawym wydaje się, czy owe założenie - założenie o pro - informacyjnym nastawieniu podmiotów zobowiązanych informacyjnie będzie miało zastosowanie w praktyce, wówczas gdy planowane uregulowania (p.u.j.ż.p.) zostaną uchwalone i wejdą w życie. 
nego biuletynu - BIP. Podobnie jak na gruncie art. 10 ust. 1 u.d.i.p. projektodawca przewiduje, że informacja publiczna, która nie została udostępniona w BIP lub centralnym repozytorium jest udostępniana na wniosek. Zakres informacji podlegających obligatoryjnemu upublicznieniu w elektronicznym biuletynie wytycza brzmienie art. 7 p.u.j.ż.p. oraz uregulowania szczególne m. in. z zakresu materialnego prawa administracyjnego. Podkreślenia znaczenia procesu generalnego upubliczniania danych należy doszukiwać się w treści ust. 3 i 5 przywołanej powyżej regulacji. Sprowadza się ono do:

- obciążenia podmiotów zobowiązanych informacyjnie obowiązkiem jednoczesnego udostępniania w BIP także tych danych, które zostały udostępnione w oparciu o wniosek złożony przez zainteresowanego na piśmie;

- obciążenia podmiotów zobowiązanych informacyjnie obowiązkiem jednoczesnego udostępnienia w BIP tych danych, które podlegają udostępnieniu przy użyciu tzw. fakultatywnych sposobów upubliczniania danych $^{30}$ - pod warunkiem, że charakter informacji umożliwi tego rodzaju sposób upublicznienia.

W zakresie doszukiwania się szczególnej roli i znaczenia procesu udostępniania informacji w BIP warto również przywołać uregulowanie art. 20 ust. 4 p.u.j.ż.p. Stosownie do jego treści organy kolegialne pochodzące $z$ wyborów powszechnych będące podmiotami zobowiązanymi informacyjnie, są obarczone powinnością sporządzenia i udostępnienia protokołu z obrad w BIP. W tego rodzaju protokołach zamieszcza się wyniki imiennego lub elektronicznego głosowania.

Z istoty pierwszeństwa trybu bezwnioskowego (przy pomocy BIP) wynika, że brak upublicznienia informacji wyczerpującej znamiona wiedzy publicznej skutkuje koniecznością udostępnienia konkretnej - oczekiwanej informacji w trybie wnioskowym ${ }^{31}$. Tego samego nie można odnaleźć w przypadku działania informacyjnego przebiegającego w tzw. drugą stronę. Fakt udostęp-

30 Chodzi w tym wypadku o udostepnienie informacji publicznej poprzez wyłożenie lub wywieszenie informacji w miejscach ogólnie dostępnych oraz o udostępnienie informacji poprzez zainstalowanie w miejscach ogólnie dostępnych urządzeń umożliwiających zapoznanie się z tego rodzaju informacją (art. 13 ust. 4 p.u.j.ż.p.).

31 Kwestia pierwszeństwa upubliczniania danych w BIP uwidacznia się na gruncie art. 19 ust. 6 p.u.j.ż.p. w ramach to którego projektodawca podnosi, że organy władzy publicznej, organy kolegialne komisji sejmowych i senackich, komisji rad jednostek samorządu terytorialnego, komisji Rady m.st. 
nienia informacji w trybie wnioskowym nie zwalnia (w świetle art. 13 ust. 3 p.u.j.ż.p.) z opublikowania jej przy pomocy elektronicznego urzędowego publikatora, jeżeli wniosek zainteresowanego przybiera formę pisemną.

\section{Pojęcie osoby pełniącej funkcje publiczne}

W grupie zmian sprowadzających się do ukształtowania ustawowych definicji pojęć występujących lub też wykorzystywanych od początku obowiązywania u.d.i.p. (1.01.2002), warto powrócić do pkt. $10 \mathrm{w}$ art. 2 ust. 1 p.u.j.ż.p. Co istotne sama treść przywołanej regulacji nie kreuje niczego nowego, nie kształtuje nowatorskiego znaczenia pojęcia osoby pełniącej funkcje publiczne, o której to działalności informacje stanowią wiedzę publiczną. Tego rodzaju kategoria osób (pomimo braku jej jednoznacznego kwalifikowania i odwoływania się w przedmiocie określenia jej znaczenia do twierdzeń doktrynalnych oraz orzecznictwa) była znana - jest znana już polskiemu ustawodawstwu. Nie należy jednakże zapominać, że pod rządami uregulowań u.d.i.p brak niniejszego ustawowego określenia doprowadził do wytworzenia rozmaitych stanowisk przesądzających o znaczeniu merytorycznym tego rodzaju podmiotu zobowiązanego informacyjnie. Na potrzebę ujednolicenia sposobów interpretowania pojęcia osoby pełniącej funkcje publiczne wskazywał B. Banaszak posługując się argumentem występowania zamętu znaczeniowego w związ$\mathrm{ku} \mathrm{z}$ brakiem normatywnego jej określenia (brakiem określenia na gruncie u.d.i.p. ${ }^{32}$. Jak podkreślono w jednym z wyroków Trybunału Konstytucyjnego „pojęcie „osoba publiczna” nie jest równoznaczne z kategorią „osoby pełniącej funkcje publiczne”. Ten pierwszy termin jest znacznie szerszy i obejmuje również osoby zajmujące w życiu publicznym pozycję dominującą, pozycję istotną z punktu widzenia kształtowania postaw i opinii społecznej ${ }^{33}$. Obejmuje osoby, które wzbudzają powszechne zainteresowanie ze względu na te

Warszawy, komisji dzielnic utrwalają przebieg swoich obrad za pomocą urządzenia rejestrującego obraz i dźwięk. Materiały zarejestrowane udostępnia się na wniosek, o ile nie są udostępnione w BIP.

32 B. Banaszak, Konstytucja Rzeczpospolitej Polskiej. Komentarz, Warszawa 2009, s. 311 - podaje za A. Bobiec, Informacja publiczna a ochrona prywatności osób petniących funkcje publiczne, [w:] Jawność w samorzadzie..., s. 60 .

33 Wyrok Trybunału Konstytucyjnego z 20 marca 2006 r., sygn. akt K 17/05, OTKZU 3A/2006, poz. 30 . 
lub inne ich dokonania, np. artystyczne, naukowe czy sportowe" ${ }^{34}$. To osoby, które pozostają $\mathrm{w}$ określonego rodzaju związku z instytucją publiczną, z organem władzy publicznej przez nich „reprezentowanym” w procesie realizacji zadania publicznego (z wyłączeniem tych osób, które wypełniają wyłącznie zadania usługowe czy też techniczne) ${ }^{35}$. Pośród niniejszych form definiowania swoje miejsce odnajduje również to, o którym mowa we wspomnianym powyżej pkt. 10 p.u.j.ż.p. W myśl przywołanej regulacji przez osobę pełniącą funkcję publiczną należy rozumieć osobę o której mowa w art. $115 \$ 19$ ustawy z 6 czerwca 1997 r. - Kodeks karny (dalej zw. k.k.) ${ }^{36}$. Jest nią funkcjonariusz publiczny, członek organu samorządowego, osoba zatrudniona w jednostce organizacyjnej dysponującej środkami publicznymi, chyba że wykonuje ona wyłącznie czynności usługowe, a także inna osoba, której uprawnienia i obowiązki w zakresie działalności publicznej są określone lub też uznane przez ustawę lub wiążącą Rzeczpospolite Polską umowę międzynarodową. Z kolei $\$ 13$ determinuje pojęcie funkcjonariusza publicznego, do którego odwołuje się doktryna pod rządami obowiązującej u.d.i.p. Pomimo braku bezpośredniego odesłania do uregulowań k.k. na płaszczyźnie p.u.j.ż.p. i jednoczesnego braku tzw. samodzielnego zobrazowania niniejszej kategorii podmiotów, za funkcjonariusza publicznego należy uznać osobę, której znaczeniem posługuje się dotychczasowy ustawodawca (art. $115 \$ 13$ k.k.). Ogół przedstawionych poglądów uwidacznia szerokie kwalifikowanie przedmiotowego pojęcia - pojęcia znanego już od początku istnienia kategorii dostępu, choć nie przez samego „twórcę” u.d.i.p. Słusznie zauważa A. Bobiec, że zarówno ustawodawca (jak i aktualnie projektodawca) nadaje niniejszemu określeniu osoby pełniącej funkcję publiczną szerokie znaczenie. Chodzi w tym wypadku o interpretację szerszą, aniżeli sam funkcjonariusz publiczny a węższą niż osoba publiczna, przy jednoczesnym usunięciu z niniejszego kwalifikowania osób, które z racji zatrudnienia (z punktu widzenia strukturalnego) w urzędach obsługujących organy władzy publicznej mogłyby podlegać tego rodzaju kategoryzacji, ale w związku z realizacją wyłącznie czynności technicznych

34 Ibidem.

35 Wyrok WSA w Warszawie z 6 listopada 2013 r., II SA/Wa 1302/13, http://orzeczenia.nsa.gov. pl/doc/4A29F0FA51 (25.04.2018), wyrok WSA we Wrocławiu z 23 października 2013 r., IV SA/Wr 510/13, http://orzeczenia.nsa.gov.pl/cbo/search (25.04.2018).

36 Dz.U. 2017, poz. 2204 ze zm. 
czy też usługowych są z niej jednoznacznie wykluczeni ${ }^{37}$. Różnica pomiędzy przywołanymi powyżej uregulowaniami (u.d.i.p. oraz p.u.j.ż.p.) sprowadza się do normatywnego definiowania osoby pełniącej funkcje publiczne - co więcej definiowania na poziomie ustawodawstwa ogólnego. Temu działaniu projektodawcy należy przypisać pozytywną ocenę, m.in. poprzez dopatrywanie się w jego ramach pro - ochronnego nastawienia względem realizacji interesu informacyjnego. Podłożem dla zajęcia niniejszego stanowiska jest dążenie do usunięcia wątpliwości interpretacyjnych oraz zamysł wyeliminowania potrzeby sięgania do odrębnego ustawodawstwa (niekoniecznie związanego z kwestiami dostępu do wiedzy publicznej). P. Sitniewski podnosi, że wejście w życie uregulowań p.u.j.ż.p. pociągnie za sobą rozszerzenie zakresu podmiotowego osób pełniących funkcje publiczne w porównaniu do katalogu wypracowanego przez aktualnie występujące orzecznictwo ${ }^{38}$.

IX. Proceduralne kwestie udostępnienia informacji publicznej

Proces udostępnienia przybierający postać czynności materialno - technicznej powinien zostać zrealizowany bez zbędnej zwłoki, nie później jednakże niż w ciągu 30 dni od dnia złożenia wniosku. O ustanowieniu nowego krótszego terminu (jako nowości na gruncie p.u.j.ż.p.) zostało już wskazane uprzednio. Co jednak ważne, przy okazji zagadnienia terminowości procesu udostępnienia uwidacznia się występowanie nowej (na gruncie uregulowań dotyczących dostępu) instytucji ustanowionej z myślą o ochronie interesu informacyjnego potencjalnie zainteresowanych jednostek ${ }^{39}$. Chodzi w tym wypadku o ponaglenie, którego prawo wniesienia aktywizuje się $\mathrm{w}$ momencie niezałatwienia wniosku o udostępnienie oczekiwanej informacji w terminie podstawowym (bez zbędnej zwłoki, 14 dni oraz 30 dni od dnia przedłożenia wniosku). Jest ono znane polskiemu ustawodawcy, jeśli weźmiemy pod uwagę brzmienie art. $141 \$ 1$ ustawy z 29 sierpnia 1997 r. - Ordynacja podatkowa ${ }^{40}$. Warto w tym miejscu zauważyć, że uwzględniając istotę instytucji ponaglenia, celowość ustanowienia i jej funkcjonalność można stwierdzić, że posiada ona wymiar instrumentu zapobiegania kierowaniu skarg na bezczynność, co ma miejsce w sytuacji niezałatwienia żądania informacyjnego w wyzna-

\footnotetext{
A. Bobiec, op.cit., s. 59.

P. Sitniewski, op.cit.

Wyrok TK z 16 września 2002 r., K 38/01, OTK ZU 5A/2002, poz. 59.

Dz.U. 2018, poz. 800 ze zm.
} 
czonym ustawowo terminie. Ponaglenie wnosi się do podmiotu, do którego złożono wniosek o udostępnienie informacji publicznej. Podlega ono rozpoznaniu w terminie 7 dni od dnia jego otrzymania.

Pewnego rodzaju novum stanowi również określona w art. 16 ust. 3 p.u.j.ż.p. instytucja pozostawienia postępowania bez rozpoznania (w miejsce występującej dotychczas decyzji o umorzeniu postępowania). Prawo do jego wniesienia aktualizuje się, wówczas gdy udostępnienie informacji w formie oraz przy użyciu sposobu określonego przez zainteresowanego nie jest możliwe, a jednostka zignoruje powiadomienie pochodzące od podmiotu zobowiązanego informacyjnie. Brak nowego wniosku - wniosku możliwego do zrealizowania przez podmiot zobowiązany - jak wskazuje projektodawca - skutkuje pozostawieniem postępowania bez rozpoznania (art. 16 ust. 3 p.u.o.j.ż.p.). O ile tego rodzaju zmiana (eliminując konieczność wydania decyzji administracyjnej) zasługuje na pozytywną ocenę, o tyle zastanawiającym jest czy posłużenie się przez projektodawcę sformułowaniem odnoszącym się do pozostawienia postępowania bez rozpoznania jest prawidłowe. Czy nie właściwszym określeniem byłoby pozostawienie wniosku, a nie postępowania o udostępnienie bez rozpoznania ${ }^{41}$ ? Wydaje się to o tyle słuszne, albowiem instytucja pozostawienia bez rozpoznania jest już znana polskiemu ustawodawstwu. Na gruncie art. $64 \$ 2$ k.p.a. ustawodawca wskazuje na konieczność pozostawienia podania - czyli m.in. żądania zainteresowanego (w myśl art. $63 \$ 2$ k.p.a.) bez rozpoznania, wówczas gdy nie spełnia ono wymagań przewidzianych przepisami prawa. Wprawdzie postępowanie w sprawie udzielenia informacji publicznej jest jedynie quasi postępowaniem administracyjnym, a przepisy k.p.a posiadają zastosowanie od momentu wydania decyzji administracyjnej, niemniej jednak niepotrzebnym wydaje się tworzenie zamętu terminologicznego i wprowadzanie instytucji proceduralnej nieznajdującej żadnego odzwierciedlenia w uregulowaniach procesowych. Wydaje się to zasadne tym bardziej, jeśli zajmiemy stanowisko, w świetle którego to właśnie wniosek a nie całe postępowanie jest obarczone pewnego rodzaju wadami (niedoskonałościami). Chodzi w tym wypadku o wady polegające na niewłaściwym - (bo niemożliwym do zrealizowania) określeniu przez jednostkę formy lub sposobu jej zaspokojenia informacyjnego (procesu udostępnienia informacji publicznej).

${ }^{41}$ Zob. stanowisko P. Sitniewskiego, - P. Sitniewski, op.cit. 


\section{Projektowany rejestr umów cywilnoprawnych}

W poszukiwaniu tzw. nowych instytucji prawnych przewidzianych przez projektodawcę na gruncie p.u.j.ż.p. na szczególną uwagę zasługuje rejestr umów cywilnoprawnych, których przedmiotem jest dostarczanie dóbr, świadczenie usług lub też realizacja robót budowlanych. Posłużenie się nim przez projektodawcę pozostaje $\mathrm{w}$ ścisłym związku $\mathrm{z}$ dążeniem do tworzenia coraz szerszej płaszczyzny przestrzegania przez uczestników zamówień publicznych zasad zdeterminowanych treścią art. 7 ustawy z 29 stycznia 2004 r. Prawo zamówień publicznych ${ }^{42}$. Co istotne w zakresie przywołanej instytucji można doszukać się ustanowienia przez projektodawcę nowego sposobu udostępniania informacji publicznej. Odwołując się do dotychczasowych rozwiązań prawnych należałoby przypomnieć, że ustawodawca posługując się art. 7 u.d.i.p. determinuje prawnie dopuszczalne sposoby upubliczniania danych wyczerpujących znamiona wiedzy publicznej. Chodzi w tym wypadku o udostępnianie informacji przy pomocy BIP, centralnego repozytorium, wyłożenia lub wywieszenia informacji w miejscach ogólnie dostępnych, bądź też za pomocą zainstalowanych urządzeń umożliwiających odczytanie (a tym samym ogólnie określając pozyskanie) informacji publicznej. Podobne rozwiązania zostały umiejscowione na płaszczyźnie p.u.j.ż.p. ${ }^{43}$ Istotniejsze znaczenie posiada natomiast to, że obok dotychczasowych sposobów udostępniania danych publicznych, projektodawca daje coś więcej, a mianowicie możliwość zapoznania się $\mathrm{z}$ danymi umiejscowionymi w rejestrach umów cywilnoprawnych zawieranych przez jednostki sektora finansów publicznych ${ }^{44}$, bank państwowy, przedsiębiorstwa państwowe, instytuty badawcze, spółki zobowiązane oraz (co najbardziej kontrowersyjne) spółdzielnie mieszkaniowe. Chodzi w tym wypadku o gwarantowany prawnie proces upubliczniania (z jednoczesną możliwością sortowania i przeszukiwania) informacji - szczególnego rodzaju, tj. umów cywilnoprawnych zawartych w formie pisemnej lub też umów cywilnoprawnych będących in-

42 Dz.U. 2017, poz. 1579 ze zm.

$43 \mathrm{Z}$ tym jednak, że projektodawca zrezygnował z posługiwania się zarówno pojęciem dostępu i wstępu na posiedzenia, które pierwotnie wywoływały rozbieżności znaczeniowe pociągając za sobą konieczność szczegółowej interpretacji. Aktualnie mowa jest o jawności i o dostępności do posiedzeń obejmujących również uprawnienie zainteresowanego do fizycznego wstępu na salę obrad.

44 Zob. rozdział3 ustawy z 27 sierpnia 2009 r. o finansach publicznych (Dz.U. 2017, poz. 2077 ze zm.). 
strumentem wydatkowania środków pieniężnych o wartości co najmniej 2.000 złotych. Udostępnienie następuje poprzez zamieszczenie informacji w BIP lub też na stronach internetowych niebędących stronami BIP. W samym uzasadnieniu projektu podkreślono, że utworzenie przedmiotowego rejestru w ujęciu bezpośrednim ma służyć kontroli prawidłowości zarządzania majątkiem publicznym i pośrednio ma przyczyniać się do przeciwdziałania korupcji ${ }^{45}$. Ma to doprowadzić do wzmocnienia przejrzystości życia publicznego w obszarze dysponowania funduszami publicznymi, dzięki któremu nastąpi zwiększenie zaufania obywateli do organów władzy publicznej i innych instytucji realizujących zadania publiczne, bądź też zarządzających środkami publicznymi ${ }^{46}$. Warto jednakże zauważyć, że w obszarze tego rodzaju udostępniania danych publicznych projektodawca celowo lub też niecelowo) tworzy nie tylko szczególną grupę informacji publicznej (poprzez wyjęcie rejestru z ogólnego katalogu danych o sprawach publicznych), ale również kształtuje odrębny rodzaj podmiotów zobowiązanych informacyjnie, którym przyznaje szczególne uprawnienie do tzw. nieprowadzenia strony BIP. W tym miejscu słusznym wydaje się zwrócenie uwagi, że od początku obowiązywania uregulowań u.d.i.p. ustawodawca nie dokonywał różnicowania podmiotów zobowiązanych informacyjnie i ich zobowiązań adekwatnie do prawnie gwarantowanych sposobów udostępniania. W szczególności zaś nie determinował szczególnego katalogu podmiotów, które będąc zobowiązanymi informacyjnie w myśl art. 4 u.d.i.p. nie byłyby obligowane do prowadzenia BIP i udostępniania przy jego pomocy informacji publicznych objętych zasadą pierwszeństwa trybu bezwnioskowego. Odmiennie zaś sytuacja wygląda, jeśli uwzględnimy brzmienie art. 9 ust. 4 p.u.j.ż.p., albowiem podmioty wymienione na gruncie ust. 1 udostępniają rejestr w BIP, a gdy podmiot ten nie prowadzi BIP - na odrębnej i niezależnej stronie internetowej. Ponadto projektodawca uwidacznia odrębny (od katalogu ogólnego określonego na gruncie art. 8) zespół ograniczeń w dostępności (w odniesieniu do przeglądania zawartości rejestru umów) ${ }^{47}$.

45 Uzasadnienie do p.u.o.j.ż.p., http://www.jawnosc.pl/?p=3438 (21.04.2018).

46 Ibidem.

47 Zob. art. 9 ust. 5-8 p.u.j.ż.p. W przypadku ograniczeń, tj. w zakresie nieudostępniania rejestru umów informacje podlegają przekazaniu Szefowi Centralnego Biura Antykorupcyjnego na koniec miesiąca, w którym miało miejsce zawarcie umowy lub wprowadzenie zmian do jej zawartości. 


\section{Dostęp do posiedzeń organów kolegialnych pochodzących $\mathrm{z}$ wyborów powszechnych}

W zakresie wspomnianych powyżej katalogów tworzonych przez projektodawcę na gruncie p.u.j.ż.p. w pierwszej kolejności należy odnieść się do zawartości art. 20 ust. 1. Na jego płaszczyźnie dochodzi do wyodrębnienia tych organów i podmiotów, których posiedzenia są jawne i dostępne. Jak zostało już uprzednio wskazane aktualnie obowiązujące uregulowania u.d.i.p. również posługują się konstrukcją jawności posiedzeń, nadając jej miano jednego $\mathrm{z}$ instrumentów realizacji zobowiązania informacyjnego ${ }^{48}$. Determinują kwestię szeroko interpretowanego dostępu do posiedzeń ( $w$ postaci faktycznego uczestnictwa zainteresowanego lub też $\mathrm{w}$ formie transmisji, dostępności do protokołu i innych materiałów rejestrujących ich przebieg) oraz wyłącznie fizycznego wstępu na posiedzenia. W żadnym jednak razie nie wyznaczają katalogu podmiotów do których odnosi się tego rodzaju zobowiązanie informacyjne, poza ogólnym określeniem, że chodzi o posiedzenia organów kolegialnych pochodzących z wyborów powszechnych. Konkretnej odpowiedzi na poniższą kwestię dostarcza od początku obowiązywania u.d.i.p. doktryna i orzecznictwo. Projektodawca w tzw. nowych uregulowaniach „idzie o krok dalej”, wyodrębnia niniejsze podmioty samodzielnie ${ }^{49}$, przewidując jednocześnie, że posiedzenia komisji wewnętrznych w organach jednostek samorządu terytorialnego są jawne i dostępne ${ }^{50}$. W porównaniu do ogólnie zdeterminowanego treścią u.d.i.p. katalogu organów kolegialnych będących zobowiązanymi informacyjnie, nowo przyjęty sposób wyznaczenia ich katalogu może determinować nie do końca prawidłowy (bo wąski) sposób

48 Będącego zarówno formą jak i sposobem przy pomocy, którego zainteresowana jednostka może pozyskać oczekiwane przez nią informacje.

49 Pod rządami uregulowań u.d.i.p. tego rodzaju posiedzenia - posiedzenia komisji jako organów wewnętrznych w jednostkach samorządu terytorialnego również były (są) jawne, ale podstaw tego rodzaju jawności należy poszukiwać na gruncie art. 11 b ustawy z 8 marca 1990 r. o samorządzie gminnym (Dz.U. 2017, poz. 1875 ze zm.), na gruncie art. 8a ustawy z 5 czerwca 1998 r., o samorządzie powiatowym (Dz.U. 2017, poz. 1868), na gruncie art. 15 a ustawy z 5 czerwca 1998 r. o samorządzie województwa (Dz.U.2017, poz. 2096).

so Projektodawca zobligował również kolegialne organy władzy publicznej oraz jednostki pomocnicze samorządu terytorialnego do konieczności utrwalania przebiegu swoich obrad za pomocą urządzeń rejestrujących dźwięk i obraz (zob. art. 19 ust. 6 p.u.j.ż.p.). 
ich postrzegania. Co jednak ważne wydaje się, że nie do końca słusznym byłoby kierowanie zarzutów pod adresem p.u.j.ż.p., stosownie do których utworzenie niniejszego katalogu prowadzi do ograniczenia zakresu podmiotów zobowiązanych informacyjnie. Nie mogłyby one odnaleźć swojego uzasadnienia, jeżeli uprzednio dokonywane interpretacje doktrynalne odnoszące się do instrumentu dostępności do posiedzeń organów pochodzących z wyborów powszechnych od strony podmiotowej (co do zasady) wykazują tożsamość zakresowo - znaczeniową ${ }^{51}$. Nie bez znaczenia w tym zakresie pozostaje również posłużenie się przez projektodawcę (podobnie jak ustawodawca na gruncie u.d.i.p.) generalnym określeniem posiedzeń kolegialnych organów władzy publicznej, dającym wbrew pozorom (w obliczu braku ich ustawowej definicji) szerokie pole interpretacyjne. Z drugiej jednakże strony przyjrzenie się przedmiotowym aspektom omawianej dostępności do posiedzeń, w szczególności w konfrontacji z uregulowaniami u.d.i.p., uwidacznia pewnego rodzaju zawężenie - ograniczenie prawa dostępu do bieżących oraz następczych form realizacji jawności posiedzeń. Chodzi w tym wypadku m.in. o zwolnienie organów władzy publicznej $\mathrm{z}$ zobowiązania $\mathrm{w}$ zakresie zagwarantowania lokalowych oraz technicznych warunków uczestnictwa w posiedzeniach każdemu zainteresowanemu oraz z konieczności zagwarantowania w miarę potrzeby transmisji audiowizualnej lub teleinformatycznej (art. 20 ust. 2 p.u.o.j.ż.p.). Podobne stanowisko należy zająć jeśli chodzi o upublicznianie materiałów mających na celu udokumentowanie przebiegu obrad. O ile przez pryzmat obowiązujących w omawianym przedmiocie uregulowań u.d.i.p. można mówić o wszechobowiązującej obligatoryjności publikowania (udostępniania) wszelkiej dokumentacji niniejszego rodzaju, przez wszystkie organy kolegialne pochodzące $\mathrm{z}$ wyborów powszechnych (stanowi o tym ustawodawca na gruncie art. 18-20 u.d.i.p.), o tyle pełna obligatoryjność z punktu widzenia podmiotowego na gruncie p.u.o.j.ż.p. dotyczy wyłącznie protokołów publikowanych w BIP (art. 20 ust. 4 p.u.o.j.z.p.). W zakresie publi-

51 Posłużenie się w tym wypadku sformułowaniem: „co do zasady” jest w pełni uzasadnione, wyjątkiem od tej reguły jest z pewnością pominięcie przez projektodawcę na płaszczyźnie p.u.o.j.ż.p. fakultatywnej jawności w zakresie posiedzeń organów pomocniczych podmiotów zobowiązanych informacyjnie. Ustawodawca na gruncie u.d.i.p. wskazuje, że posiedzenia kolegialnych organów pomocniczych podmiotów zobowiązanych informacyjnie są jawne i dostępne, o ile tak stanowią przepisy ustaw, albo akty wydane na ich podstawie lub gdy organ pomocniczy tak postanowi (art. 18 ust. 2 u.d.i.p.). 
kowania stenogramów oraz materiałów audiowizualnych i teleinformatycznych rejestrujących przebieg posiedzenia, zobowiązanie niniejsze nie objęło swoim zakresem w świetle art. 20 ust. 5 p.u.o.j.ż.p. organów jednostek pomocniczych w jednostkach samorządu terytorialnego.

\section{Rozszerzenie katalogów przedmiotowo- podmiotowych procesu udostępnienia}

Na zakończenie prowadzonych rozważań koniecznym wydaje się odniesienie do kwestii rozszerzenia dotychczas występujących katalogów determinujących informacje za posiadające status wiedzy publicznej, czy też kwalifikujących określonego rodzaju podmioty za zobowiązane informacyjnie. Nie bez znaczenia pozostaje również częściowo zmieniony i jednocześnie rozszerzony katalog ograniczeń procesu udostępniania ze względu na wartości wymagające ochrony (katalog ograniczeń ze względu na konieczność ochrony tajemnic publicznoprawnych i prywatnoprawnych) oraz wyłączeń od tego rodzaju ograniczeń w myśl zasady ograniczonej dostępności, czy też względnej dostępności.

W zakresie rozszerzenia katalogu ściśle przedmiotowego uwidacznia się objęcie zakresem informacji publicznej podlegającej udostępnieniu w sposób powszechny danych dotyczących umorzeń (ulg) w spłacie zobowiązań podatkowych poszczególnych podmiotów, dotyczących wydatków ze środków publicznych dokonywanych za pomocą służbowych kart płatniczych w tym także w spółkach zobowiązanych, dotyczących stanu zatrudnienia na podstawie umowy o pracę. Rozszerzenie katalogu informacji noszących znamiona wiedzy publicznej objęło również dane dotyczące postępowań administracyjnych oraz ekspertyzy i opinie finansowane ze środków publicznych. Od strony podmiotowej rozrost katalogu skupił się na objęciu jego zakresem spółdzielni mieszkaniowych. Tym samym stały się one w myśl p.u.j.ż.p. jednoznacznie zdeterminowanymi przez projektodawcę podmiotami zobowiązanymi w przedmiocie udostępniania informacji publicznej. Jednoczesne wyróżnienie przedstawionych powyżej rozszerzeń katalogów podmiotowo - przedmiotowych na gruncie niniejszego opracowania nie posiada przypadkowego charakteru. $\mathrm{W}$ obu przypadkach ich wprowadzenie 
przez projektodawcę może zostać ocenione negatywnie. Dla oceny słuszności tego rodzaju opinii koniecznym jest rozróżnienie dwojakiego rodzaju punktów widzenia. Uwzględniając ogólne założenie względem konstrukcji dostępu do informacji publicznej, należy wskazać że jak najszerszy katalog informacji publicznej oraz jak najszerszy katalog podmiotów zobowiązanych informacyjnie świadczy o wysokim poziomie zaspokojenia informacyjnego oraz przesądza o występowaniu szerokich możliwości społecznego kontrolowania. Jest to szczególnie ważne w czasach współczesnych, gdzie m.in. na skutek tzw. nowych technologii istotne znaczenie odgrywa efektywny transfer informacji, w szczególności zaś informacji publicznej. Sięgając jednakże głębiej nie należy zapominać o konieczności zachowania proporcji, zrównoważenia w procesie udostępniania, tak aby proces upubliczniania danych noszących znamiona wiedzy publicznej nie naruszał praw (interesów) innych jednostek (aby za głęboko nie ingerował w prawo do prywatności ${ }^{52}$. W jednym z wyroków Trybunału Konstytucyjnego zostało podkreślone, że ustawodawca musi "wyważyć” wszystkie wartości z uwzględnieniem treści art. 31 ust. 3 Konstytucji, tak aby realizacja ochrony interesu publicznego i informacyjnego jednostki nie uderzała w interesy i wartości innych jednostek oraz aby nie zagrażała bezpieczeństwu państwa ${ }^{53}$. Słusznie zauważa L. Bielecki, że prawodawca w swych działaniach (nawet jeśli czynności są podejmowane z myślą o kontrolowaniu społecznym) nie może nadużywać uprawnień i wolności obywatelskich ${ }^{54}$. Sama zaś jednostka powinna korzystać z gwarantowanych mu legitymacji prawnych w sposób rozsądny, racjonalny, przemyślany i odpowiedzialny. Nie można udostępniać informacji ponad wszelką miarę, a zachowaniu tych szczególnych wartości, ma służyć m.in. ochrona gwarantowana w postaci ograniczeń przewidzianych na gruncie aktualnie obowiązującej u.d.i.p oraz rozszerzonych treścią p.u.j.ż.p.

52 Zob.https://www.rpo.gov.pl/pl/content/opinia-rpo-w-sprawie-projektu-ustawy-o-jawnoscizycia-publicznego (21.04.2018).

53 Wyrok TK z 19 czerwca 2002, sygn. akt. K 11/02, OTK ZU 4A/2002, poz. 43, - przywołuję podążając za stanowiskiem RPO w sprawie projektu ustawy o jawności życia publicznego: https://www. rpo.gov.pl/pl/content/opinia-rpo-w-sprawie-projektu-ustawy-o-jawnosci-zycia-publicznego (21.04.2018).

54 L. Bielecki, Zasada proporcjonalności w świetle Konstytucji RP - kwestie podstawowe, [w:] Problemy polskiej transformacji, red. J. Kornaś, Kielce 2011, s. 284, L. Bielecki, J. Stelmasiak, Zakres jawności działania organów powiatu, [w:] Jawność w samorządzie..., s. 54. 


\section{Zakończenie}

Podsumowując przedstawione rozważania należy wskazać, że projektowane zmiany w obrębie uregulowań odnoszących się do kwestii udostępniania danych publicznych słusznie wywołują skrajne emocje (od pozytywnych do negatywnych). Pomimo ogólnego założenia o rozszerzeniu zakresu jawności życia publicznego, a tym samym i o wzmocnienia realizacji interesu informacyjnego jednostki, dostrzegalne stają się również pewnego rodzaju niedociągnięcia. Zdecydowanie na pozytywną ocenę zasługuje definiowanie pojęć wcześniej występujących na gruncie u.d.i.p., ale będących niedookreślonymi. Z drugiej jednakże strony trzeba zauważyć, że część regulacji, która w swoim założeniu ma być pewnego rodzaju nowością w obrębie systemu determinującego kwestię dostępu do wiedzy publicznej, w rzeczywistości urasta do (wprawdzie pozytywnie ocenianego), ale jedynie powtórzenia rozwiązań czy też interpretacji znanych już w praktyce zaspakajania zobowiązań informacyjnych (w praktyce realizacji procesu udostępniania wiedzy publicznej). Z kolei poszerzanie katalogów podmiotowych i przedmiotowych „na pierwszy rzut oka” zasługujące na powszechną akceptację ze strony społeczeństwa, wymaga zachowania szczególnej ostrożności. Nie zawsze szeroka dostępność do danych, a tym samym szeroko gwarantowane możliwości zaspokojenia informacyjnego $\mathrm{w}$ pełni są zgodne z normatywną koniecznością ochrony innych wartości, w szczególności zaś prawa do prywatności, czy też bezpieczeństwa danych osobowych. Samo zaś wyodrębnienie katalogu ograniczeń dostępności ze względu na wartości szczególnie chronione w obliczu pozostałych uregulowań p.u.j.ż.p. może okazywać się w konkretnych sytuacjach zabiegiem niewystarczającym.

\section{Literatura}

Aleksandrowicz T., Komentarz do ustawy o dostępie do informacji publicznej, Warszawa 2008.

Banaszak B., Konstytucja Rzeczpospolitej Polskiej. Komentarz, Warszawa 2009.

Dostęp do informacji publicznej. Wybrane aspekty teorii i praktyki, red. A. Lusińska, A. Kalinowska- Żeleźnik, Gdańsk 2014.

Jawność w samorządzie terytorialnym, red. B. Dolnicki, Warszawa 2015. 
Kędzierska K., Szustakiewicz P., Pojęcie informacji publicznej, [w:] Dostęp do informacji publicznej, red. P. Szustakiewicz, Warszawa 2016.

Komentarz do ustawy z dnia 6 września 2001 ro dostępie do informacji publicznej, red. M. Kłączyński, S. Szuster, Lex/el.

Problemy polskiej transformacji, red. J. Kornaś, Kielce 2011.

Taczkowska-Olszewska J., Dostęp do informacji publicznej w polskim systemie prawnym, Warszawa 2014. 